\title{
山留支保工の工法選定に関する研究 \\ A STUDY OF DESIGN MODELS OF RETAINING SUPPORTS IN EXCAVATION WORKS
}

\author{
間 瀬 惇平*, 南林 和**, 寺林 肇**, 桂 純二*** \\ Junpei MASE, Kazu NANBA YASHI, Haïme TERABAYASHI \\ and Junji KATSURA
}

\begin{abstract}
Due to an increase in developments that are concentrated in urban areas, excavation in building construction has deepened and widened. Consequently, it has become more critical to consider the influence on neighborhood and public nuisance during construction. Underground works occupy a large part of construction costs and periods, thus being regarded as most important. This study presents planning of excavation works in building construction at an early stage.

The authors have suggested the design models for planning of retaining supports:

1) The authors have suggested three logics for planning of retaining supports identified by three Zones (A, B and C) which are categorized by degrees of Depth and Area of excavation.

2) The authors have analyzed cases which belong to Zone $A$ (small and medium-sized excavations) and Zone $B$ (large and deep sized excavations).

3) Especially, in Zone B, the authors have testified the possibility of an appropriate planning method of retaining support by the logic introduced from statistical discriminate analysis.
\end{abstract}

Keywords : Excavation works, Retaining support, Statistical analysis, Design model

掘削工事、山留支保工、統計的判断、推定モデル

\section{1. 粕震}

建設工事においてコストや工程的に地下工事の占めるウエートは 大きい。特に、都市部において、地下の高度利用や近隣環境への影 響などから、地下工事の適正な計画・実施の重要性は増大している。 しかしながら、地下工事に関する施工計画・管理技術の歴史は浅 く、それらについての方法論が十分確立しているとは言い難い。 建築工事における地下工事（根切山留工事）の計画とその施工に 関しては、

(1) 掘削地盤の土質性状と地下水状況

(2) 掘削地盤の形状と深さ、広さ

(3) 新設建物の骨組と基礎構造

(4) 近隣状況・敷地内外の状況

(5) 工期・経済性・社会情势・法的規制等

の各種要因がその都度異なるため、ケースバイケースで行われてい る。1)

この内、山留壁及び支保工の選択の基準については目安 ${ }^{2)}$ として
定性的には与えられているが、定量的な統計的判別分析手法によっ て報告されたものは筆者ら ${ }^{3)}$ 4) の研究が最近なされた状況で、いま だ緒についたところである。

そこで本論文では地下工事における過去の実績調査分析を行い、 判別分析による工法推定モデルを構築すると共に、実務経験に基づ く工法選定のモテル案を提案する。

山留壁の工法推定に関するモデルの構築と、その比較検討につい ては、参考文献 ${ }^{3)}$ に詳述されているので、本論文としては省略し、 山留支保工の工法推定モデルの構築とそれらに関する下記の技術的 考察を加えることとする。

(1) 仮設工事としても山留支保工としては、最も一般的に使用さ れるのは、鋼製 ( $\mathrm{H}$ 型鋼) 井型切梁工法 (以下、井型切梁と呼 ぶ）である。そこで統計手法により、この井型切梁工法の採用 例を分析し、採用条件を明らかにする。

(2) 次に、大規模・大深度山留に多く採用される、特殊工法とし ての「組立集中切梁工法」（以下、集中切梁と呼ぶ）、「地盤
* 大成建設侏建築本部建築部

** 大成建設侏建築本部建築技術部

*** 大成建設(敉東京支店
Building Construction Dept. Building Construction Div., Taisei Corporation Technology Promotion Dept. Building Construction Div., Taisei Corporation Tokyo Branch, Taisei Corporation 
アンカー工法」（以下、地盤アンカーと呼ぶ）、「逆打工法（1 階床先行工法含む）（以下、逆打と呼ぶ）」事例を統計手法に より分析し、その採用条件を明らかにする。

これらのことを明確にすることにより、工事計画の初期段階の山 留支保工選定を容易にし、より適切な山留工事の手順、方法、施工 計画を可能にする。

\section{2. 山留支保工事における工車の実㳟の分析}

\section{1 山留支保工の英福データ}

本報で用いる地下工事の実績デー夕は、参考文献3)4)で用いたデ 一タをもとにその一部を使用した。工事着工年の範囲は地盤アンカ 一工法が出現した 1972 年以降 1986 年までの工事を対象とした。地 域としては主として第 4 期堆積層（蚛積層、洪積首）からなる本州 6 地域（東京、大阪、名古屋、東北、広島、横浜）における工事デ ータを対象とした。また、掘削規模としては井型切梁 1 段が架かる 最小規模から工区分けなどによる複合的な施工を行わない範囲での 最大規模までとして、掘削深度は $4 \mathrm{~m} \sim 25 \mathrm{~m}$ 、掘削面積は2 00 $\mathrm{m}^{3} \sim 8000 \mathrm{~m}^{2}$ の工事を対象とした。地域別工事件数を図 1 に、山 留支保工毎の工事件数を図 2 に示す。

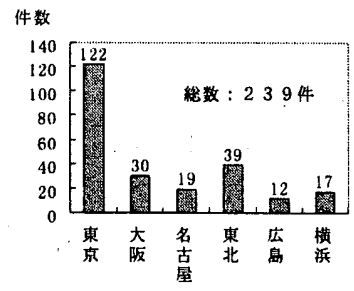

図 1 地域別工事件数

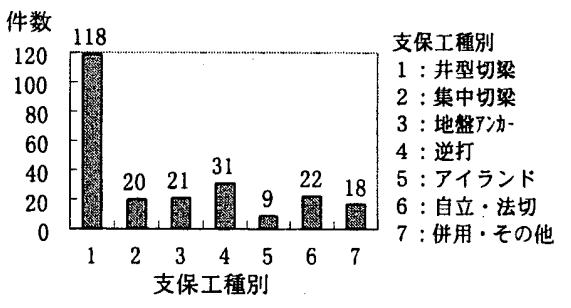

図2 支保工種別毎の工事件数

地域別の工事件数は東京地域が全体の約半数を占め、以下、東北、 大阪と続いている。支保工種類としては井型切梁が全体の約半数を 占めている。続いて、逆打工法（一階床先行工法を含む）、自立・ 法切、地盤アンカー工法、集中切梁工法の順で採用件数が多い。

本分析のための説明変数には、最も一般的な工法である井型切梁 の採用の可否を判断する指標としての掘削規模（掘削哚度、面積） 及び土圧、地下水の影響等、更に切梁の架構の可否あるいは適・不 適を判断する指標としての敖地形状、及び地盤性状等、また、逆打 立法採用に影響を与えると考えられる工程条件などから以下の 9 項 目を選択する。

(1) 掘削深度 (m)

(2) 掘削面積 ( $\left.\mathrm{m}^{2}\right)$

(3) 敷地平面形状 (平面形状の複雑性を 4 段階の重みとして示す。 矩形を 1 とする。一辺が斜めの形を 2 とする。多角形を 3 とす る、不整形を 4 とする。)

(4) 水位差（掘削深度と地下水位の差）（m）

(5) 平均N値
(地表面から根切底までの土の平均 $\mathrm{N}$ 値)

(6) 砂の割合 $(0 \sim 1)$

(地表面から根切底までの土に占める砂の割合)

(7) 砂のN値

（地表面から根切底までの砂の部分の平均 $\mathrm{N}$ 値）

(8) 粘土N值

（地表面から根切底までの粘土の部分の平均 $\mathrm{N}$ 値）

(9) 全体工期（月数）

文献 ${ }^{4)}$ では粗粒土厚が支保工選定に大きく寄与しているとの報告 があり、説明変数に粗粒土厚、細粒土厚を取っている。本分析では 砂の割合が同等の寄与をすると判断し、説明変数を絞った。

\section{2 山留支保工の工法の種䫏とその特徽}

図 3 に各支保工に対する掘削深度の箱ヒゲ図 (分析対象データ 2 39 件について）を示す。

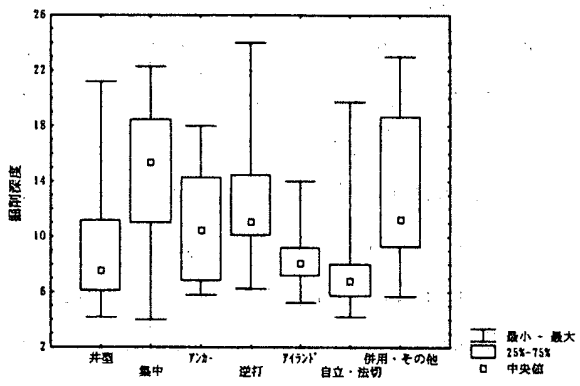

図３＼cjkstart支保工に対する掘削深度の箱ヒゲ図

井型切梁、アイランド、自立・法切工法は相対的に掘削深度の浅 い工事に適用されていることがうかがえる。地盤アンカー工法は中 間的な深度の工事に適用されている。集中切梁は掘削深度深いもの に多用されている。

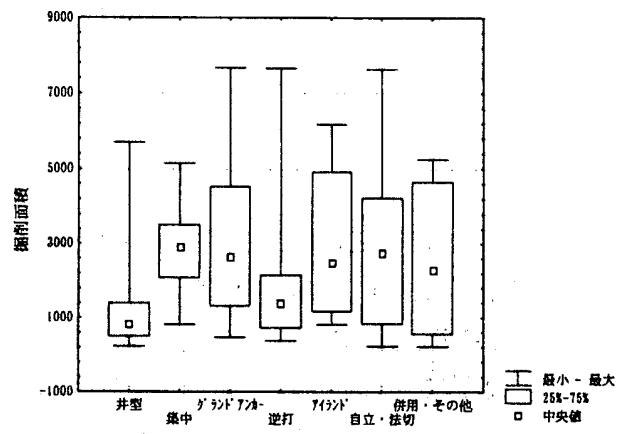

図 4 支保工に対する掘削面積の箱ヒゲ図

図 4に各支保工に対する掘削面積の箱ヒゲ図（分析対象データ 2 39 件について）を示す。井型切梁、逆打工法は相対的に掘削面積 の小さい工事に適用されていることがうかがえる。逆打工法は掘削 面積の大きい工事での適用もある。

図 3，図4から支保工法を以下の 4 つのグループに分類する。

(a)：中小規模に多い井型切梁工法グループ

(b)： 大規模、大樑度に多い集中切梁、地盤アンカー、逆打工 法グループ

（c）： 大規模だが浅い工事に多いアイランド、自立・法切工法 グループ

（d）：併用・その他の工法グループ

支保工法と掘削面積、深度に相関関係がうかがえる。分析対象 2 
39 件の事例を掘削面積と掘削深度でプロットした。図 5 にグルー プ(a)，(b)を、図6にグループ(c)，(d)をプロットした。

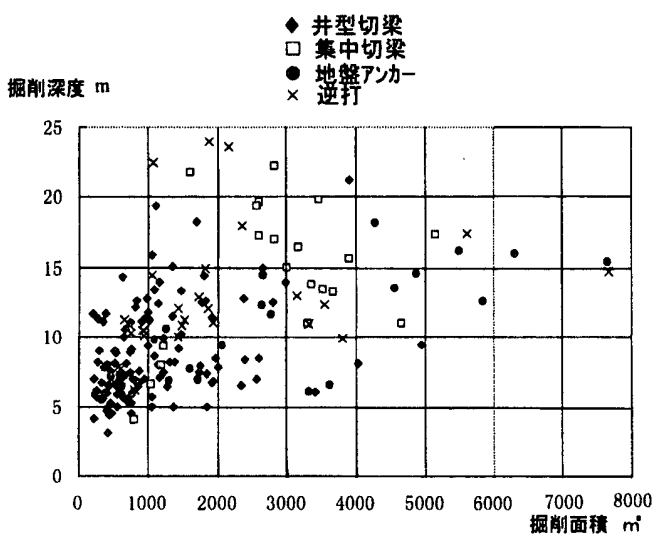

図 5 (a), (b) グループプロット図

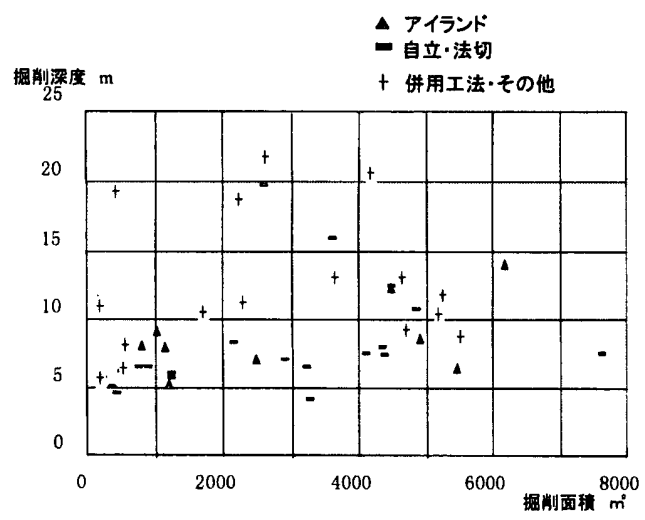

図6 (c), (d)グループプロット図

\section{3 山留支保工连定における経験者のロジック}

図 3から図6 を元に山留工事の計画・管理に携わってきた経験を 加味して、(a)から (d) グループの分類ロジックを考察すると以下の ようなことが言える。

(1) (a) グループ (井型切梁工法) は中小規模の面積、深度をカバ 一する。図 5 によると面積の上限は $2500 \mathrm{~m}^{2}(50 \mathrm{~m} \times 50$ m）あたりにありそうである。

(2) (a)グループ (井型切梁工法) は一般的に地下 2 階位までは大 丈夫である。図 5 でもそれがうかがえる。

(3) 掘削面積が小さめの場合は地下 3 階程度まで井型工法が採用 される。この場合の面積の上限は $1600 \mathrm{~m}^{2}(40 \mathrm{~m} \times 40 \mathrm{~m})$ 程度と考えられる。

(4) (c)グループのアイランド、自立・法切工法は掘削哚度 $8 \mathrm{~m}$ 程 度のところに限界がありそうである。

(5)（b)グループの集中、地盤アンカー、逆打工法は上記(1)〜(4)以 外のソーンをカバーしている。

（6）（d）グループの併用工法とその他工法は広い範囲に存在して いる。実施例をあたると、地下工事で工区分けがある場合や敷 地に高低差があり、辺毎に土压条件が変わるなど、今回の統計 的分析のためのデータ（説明変数）では表現が困難なものが大 半である。よって、（d）グループは工法選定ロジックの対象外 とする。

以上のことから掘削面積と深度による二次元エリアを $\mathrm{A}, \mathrm{B}, \mathrm{C}$
の3ソーンに分けることとする。A，B，Cの3ゾーンを図 9 に示 す。Aソーンは掘削深度 $16 \mathrm{~m}$ 以下かつ掘削面積 $1600 \mathrm{~m}$ 以下の エリアまたは掘削深度 $12 \mathrm{~m}$ 以下かつ掘削面積 2500 m以下のエ リアとする。Cゾーンは掘削深度 $8 \mathrm{~m}$ 以下かつ掘削面積 $2500 \mathrm{~m}^{2}$ 超のエリアとする。BゾーンはA，Cゾーン以外のエリアとする。

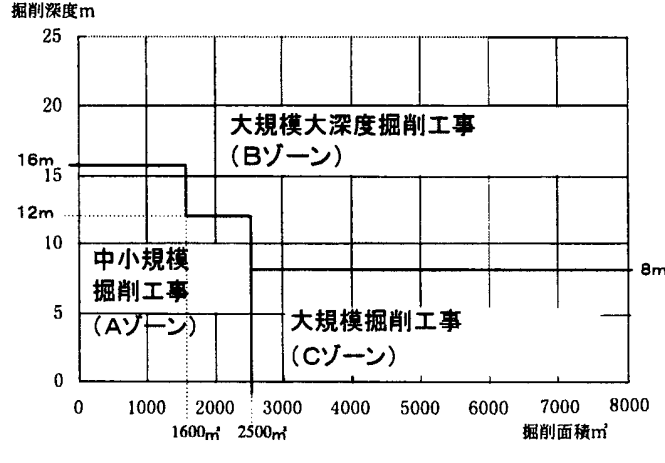

図 7 支保工選定ソーン

\section{4 Aソーン（中小規烘掘削工事）需例の判別分析}

Aソーンの事例について判別分析を行った。支保工種別毎の事例 件数を図 8 に示す。支保工なしのもの（自立・法切）、アイランド は井型切梁工法と条件がかなり異なると考えられるので判別の対象 外とした。

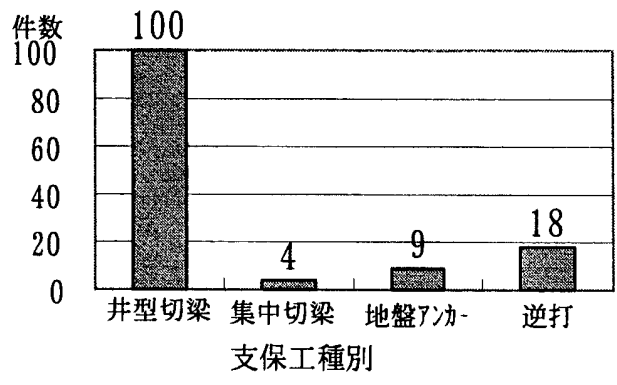

図 8 サンプルのヒストグラム

判別分析の結果を表 1 に示す。このソーンはまったくの井型切梁 ソーンと言うことができる。他の工法の特徴は判別されなかった。

表 1 Aソーンの判別分析結果

\begin{tabular}{|c|c|c|c|c|c|}
\hline \multirow[b]{2}{*}{ 真の群 } & \multicolumn{2}{|c|}{ 判別された } & \multicolumn{2}{|c|}{ 単位:件 } & \multirow{2}{*}{$\begin{array}{c}\text { 判別的中 } \\
\text { 室 }(\%)\end{array}$} \\
\hline & 井型 & 集中 & 地盤アソカー & 逆打 & \\
\hline 井型切梁 & 99 & 0 & 0 & 1 & $99 \%$ \\
\hline 集中切梁 & 4 & 0 & 0 & 0 & $0 \%$ \\
\hline 地盤アソカーー & 9 & 0 & 0 & 0 & $0 \%$ \\
\hline 逆打 & 17 & 0 & 0 & 1 & $6 \%$ \\
\hline 合計 & 129 & 0 & 0 & 2 & $76 \%$ \\
\hline
\end{tabular}

支保工種類に対する各説明変数の箱ヒゲ図を図 9〜16に示す。 箱ヒゲ図から読みとれる特徵を表 2 にまとめた。

また、Aソーン内の井型切梁以外の工法選択事例について選択理 由を考察した。Aソーンでは分析のための説明変数では判別できな いため、説明変数以外の条件が何らかの形で影響を及ぼしていると 考えられる。それらの条件と考えられるものを抽出し、条件 No.（A -1〜A-6) を付して表 3 に整理した。 
表 2Aソーンの支保工の特徵

\begin{tabular}{|c|c|}
\hline 特 & 図番号 \\
\hline 平面形状が複雑だと逆打傾向あり & 図 9 \\
\hline 掘削深度大きめ (>8m) は逆打傾向有り & 図10 \\
\hline $\begin{array}{l}\text { 掘削面積大きめ（>800〜1200 m²）は地盤アンカー傾 } \\
\text { 向あり }\end{array}$ & 図 11 \\
\hline 地下水多い（>4.5m） と逆打傾向あり & 図 12 \\
\hline $\mathrm{N}$ 値が小さい（平均 $\mathrm{N}$ 値 $<=15 ）$ と逆打傾向有り & 図 13 \\
\hline 地盤がゆるい（砂の N 值＜=15） と逆打傾向有り & 図14 \\
\hline 地盤が軟らかい（粘土 $N$ 値<＝3） と逆打傾向有り & 図15 \\
\hline $\begin{array}{l}\text { 逆打は工期が長め（>14月）の傾向あり（工期余裕 } \\
\text { 必要） }\end{array}$ & 図16 \\
\hline
\end{tabular}

表 3 Aソーンで井型切梁以外が選定される条件

\begin{tabular}{|l|l|l|r|}
\hline $\begin{array}{l}\text { 条件 } \\
\text { No. }\end{array}$ & $\begin{array}{l}\text { 支保 I } \\
\text { 種類 }\end{array}$ & 選択条件 & $\begin{array}{r}\text { 事例 } \\
\text { 件数 }\end{array}$ \\
\hline \hline $\mathrm{A}-1$ & 集中 & 細長い敷地で一方向の集中切梁 & 3 \\
\hline $\mathrm{A}-2$ & 集中 & 改良井型による集中化 & 1 \\
\hline $\mathrm{A}-3$ & $\begin{array}{l}\text { 地 盤ア } \\
\text { ンカー }\end{array}$ & $\begin{array}{l}\text { 敷地高低差がある、または } 1 \text { 辺が隣 } \\
\text { 接建物の地下で切梁が架けにくい }\end{array}$ & 9 \\
\hline $\mathrm{A}-4$ & 逆打 & 極度の軟弱地盤 & 10 \\
\hline $\mathrm{A}-5$ & 逆打 & 敷地不整形のため & 6 \\
\hline $\mathrm{A}-6$ & 逆打 & 周辺道路が狭く、作業床が必要 & 2 \\
\hline
\end{tabular}
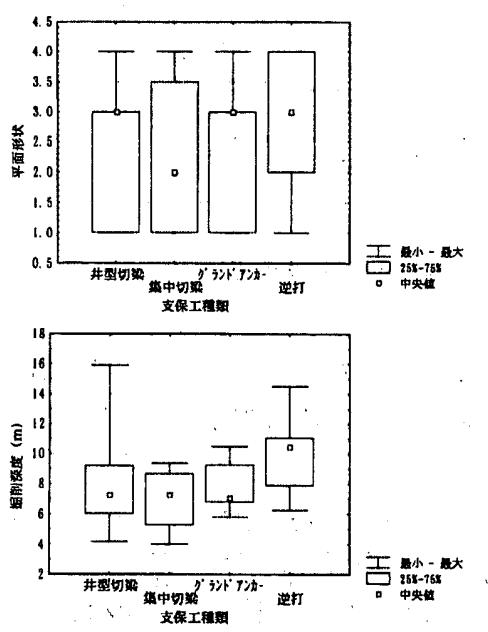

図 10 掘削深度

掘削深度大きめ

○8m) は

逆打傾向あり

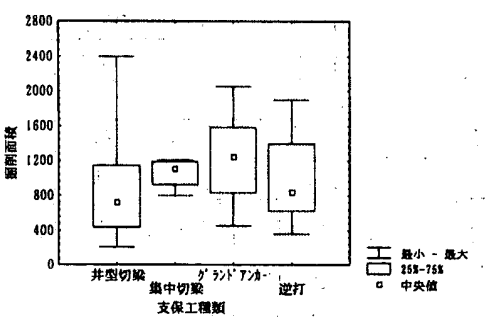

図 11 据削面積

掘削面積大きい

$\bigcirc 800 \sim 1200 \mathrm{~m})$ と地

盤アンカ一傾向あり

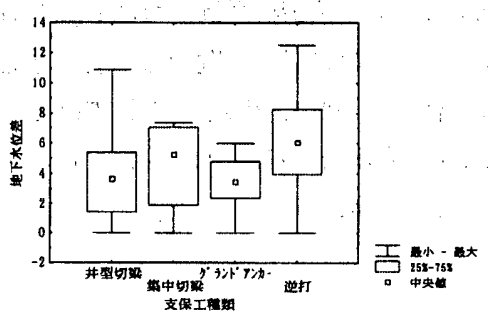

図 12 地下水位差

地下水位差が大きい（> 4. 5四）之逆打傾向あり
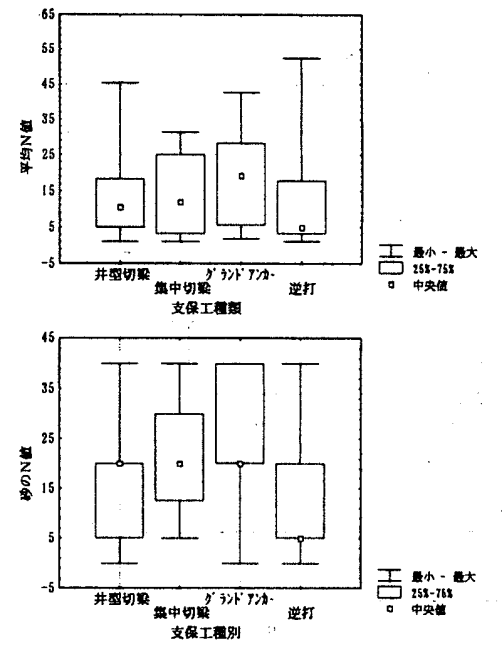

図14 砂のN值

地盤がゆるい

（砂の $\mathrm{N}$ 値<=15）と

逆打傾向あり

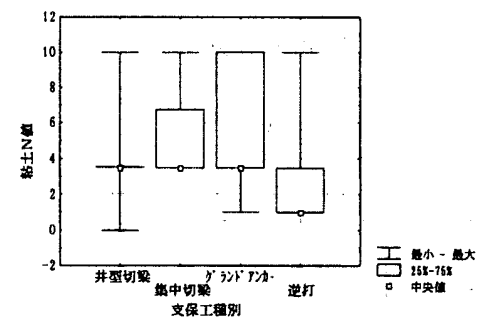

図 15 粘土N值

地盤が軟らかい

（粘土 $\mathrm{N}$ 值 $<=3$ ） と

逆打傾向あり

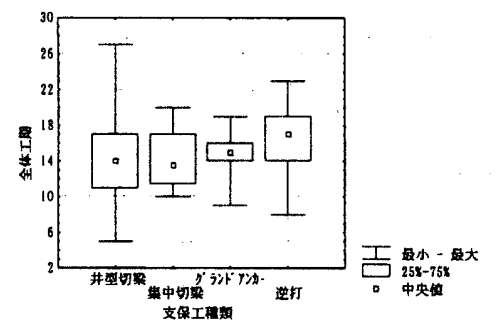

図 16 全体工期

\section{逆打は工期が長め}

(>14月）の傾向あり

(工期余裕必要)

\section{5 Bソーーン（大規措大深度排削工严）における集中切梁、地 盤アンカ一、逆打工法の判別分析}

次にBソーンの事例について判別分析を行なった。Bソーンには 井型切梁の施工例も含まれているが、2、1 節で述べたように、こ のソーンを集中切梁、地盤アンカー、逆打工法を適用するソーンと 考え、この 3 群について判別を行った。まだこのソーンにおける 井型切梁が選定される条件については後述する。

2. 1節に示した 9 項目を説明変数、「集中切梁」、「地盤アン カー」、「逆打」の 3 群を目的変数として、事例デー夕に対して正 淮判別分析を行い、判別関数式 1 及び式 2 を得た。

$\mathrm{X}=-3.95698 \times$ 砂の割合 $-1.06886 \times$ 平面形状 $-0.01516 \times$ 地下 水位差 $-0.03358 \times$ 平均 $\mathrm{N}$ 值 $-0.00013 \times$ 掘削面稹 +0.15722 $8 \times$ 掘削深度 $-0.03424 \times$ 砂のN值 $+0.007622 \times$ 全体工期 $+3.567565$ 式 1

$Y=3.910225 \times$ 砂の剖合 $-0.09166 \times$ 平面形状 $+0.098696 \times$ 地下 水位差 $-0.07553 \times$ 平均 $\mathrm{N}$ 值 $-0.00028 \times$ 掘削面積 +0.126 $627 \times$ 掘削深度 $-0.01514 \times$ 砂のN值 $-0.06897 \times$ 全体工期 $+0.009001$ 式2

サンプルの支保工種別毎の件数を図 17 に示す。

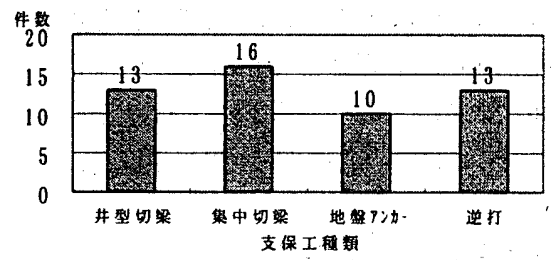

図 17 サンプルのヒストグラム 
この分析では、目的変数が 3 群であるので、正準判別分析の結果 は二次元の正準判別空間上の位置として表現できる。各工事の説明 変数の值を式 1 、及び式 2 に代入して得られる判別得点をそれぞれ $\mathrm{x}$ 座標、 $\mathrm{y}$ 座標としてプロットしたものが図 18 である。図中の各 群の「重心」とは、各工法別の説明変数とした 9 項目のうち、判別 関数に採用された 8 項目の平均値を式 1 、及び式 2 に代入して得ら れた判別得点 $\mathrm{x} 、 \mathrm{y}$ の座標値である。

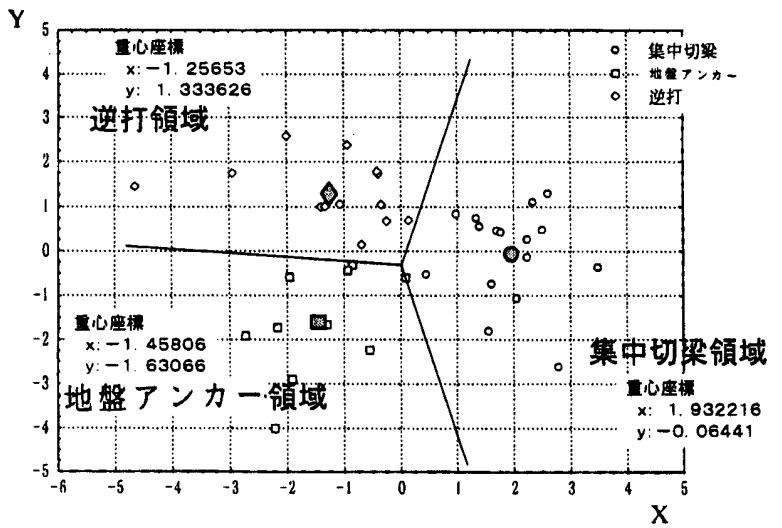

図18 Bグループの判別結果散布図

図 18 で○ (集中切梁)、口（地盤アンカー）、৩（逆打）はそ れぞれの工事において実際に採用された支保工の工法を示している。 また、例えば集中切梁領域内にプロットされた工事の支保工は、こ の判別分析により集中切梁に判別されたことを表わしている。同様 に地盤アンカー領域内の工事は地盤アンカーに、逆打領域内の工事 は逆打工法に判別された工事であることを表わしている。この $3 つ$ のソーンの各領域は 3 つの群の重心を頂点とする三角形の各辺の垂 直二等分線で区切られている。

判別分析の精度を表 4 に示した。

表 4 B ソーンの判別精度

\begin{tabular}{|c|c|c|c|c|}
\hline \multirow[b]{2}{*}{ 真の群 } & \multicolumn{2}{|c|}{ 判別された群 } & 巣位:珄 & \multirow{2}{*}{$\begin{array}{c}\text { 判別的中 } \\
\text { 率 }(\%)\end{array}$} \\
\hline & 集中切梁 & 地盤厂ン力ー & 逆打 & \\
\hline 集中切梁 & 16 & 0 & 0 & $100 \%$ \\
\hline 地盤アン力- & 1 & 9 & 0 & $90 \%$ \\
\hline 逆扛 & 0 & $\underline{0}$ & 13 & $100 \%$ \\
\hline 合計 & 17 & 9 & 13 & $97 \%$ \\
\hline
\end{tabular}

大規模工事であるBソーンでは集中切梁、地盤アンカー、逆打工 法の選定条件が $97 \%$ の精度で判別された。

各工事の判別空間内の位置について、領域の重心に近いものほど 判別条件が良い。領域境界にあるものは隣接する領域の傾向を有し ていると考えられる。また、重心から遠い位置にあるものについて もその特性を検討しておく必要がある。領域の境界付近及び重心か ら遠い位置にある事例についてその特徵を確認し、表 5 に示した。 表 5 判別空間領域の端にある事例の検証

\begin{tabular}{|c|c|c|c|}
\hline & 集中切梁 & 地盤ア劢 & 逆打 \\
\hline 領域の境界 & $\begin{array}{l}\text { アンカーリ゙ - ンに近 } \\
\text { いものは } 1 \text { 段 } \\
\text { 目にアンカをを併 } \\
\text { 用していた }\end{array}$ & $\begin{array}{l}3 \text { 件の内 } 1 \text { 件 } \\
\text { は } 1 \text { 段目に法 } \\
\text { 切工法を採用 } \\
\text { していた }\end{array}$ & $\begin{array}{l}3 \text { 件の内 } 2 \text { 件 } \\
\text { は一階床先行 } \\
\text { で下部は鋼製 } \\
\text { 切梁を採用し } \\
\text { ていた }\end{array}$ \\
\hline 重心から遠い & $\begin{array}{r}1 \text { 件: 適正な } \\
\text { 集中切梁 }\end{array}$ & $\begin{array}{c}\text { 件 : 適正な } \\
\text { 地盤ア劢- }\end{array}$ & $\begin{array}{c}1 \text { 件: 適正な } \\
\text { 逆打 }\end{array}$ \\
\hline
\end{tabular}

領域境界付近の工事は予想通り隣接領域の傾向が若千見受けられ るが実施及び判別結果の工法は妥当と考えられる。また、重心から 遠いものについては特殊な条件は見出せなかった。

表 6 に分類関数の定数項を示す。各目的変数及び説明変数毎の値 は各説明変数に対して大きい值の方がより強い相関関係を示してい る。表 6 及び図 $19 \sim 26$ の箱ヒゲ図から各支保工の特徵を抽出し 表 7 にまとめた。

表 6 分類関数の定数値

\begin{tabular}{|c|c|c|c|}
\hline & 集中 & 地盤了ン力二 & 逆扛 \\
\hline 砂の割合 & 12.44376 & 19.734638 & 30.52822 \\
\hline 平面形状 & 1.234492 & 5.00179 & 4.51468 \\
\hline 地下水位差 & 0.188744 & 0.0855566 & 0.375066 \\
\hline 平均N值 & -0.01674 & 0.215409 & -0.01526 \\
\hline 掘削面皘 & 0.002213 & 0.0030942 & 0.002236 \\
\hline 掘削深度 & 0.940347 & 0.2089717 & 0.616016 \\
\hline 砂N值 & 0.075091 & 0.2148871 & 0.163121 \\
\hline 全体工期 & 0.311538 & 0.3937251 & 0.19 \\
\hline 定数 & -19.9366 & -33.03941 & 31 \\
\hline
\end{tabular}

表 7 集中切梁、地盤アンカー、逆打工法の特徵

\begin{tabular}{|c|c|}
\hline 特 徵 & 図の No. \\
\hline $\begin{aligned} \text { 砂の割合が多い }(>0.5) \text { と逆打傾向あり } \\
\text { 少ない }(<0.4) \text { と集中切梁の傾向あり }\end{aligned}$ & 図24 \\
\hline $\begin{array}{l}\text { 平面形状複雑なものは地盤アカ准な向あり } \\
\text { 集中切梁は整形な土地の利用が多い }\end{array}$ & 図 19 \\
\hline 掘削面積広いと地盤ア劢-の傾向あり & 図2 1 \\
\hline 平均N値が大きいと地盤ア劢-傾向あり & 図23 \\
\hline 掘削深度が大きいと集中切梁の傾向あり & 図20 \\
\hline 砂のN値が小さい場合（<20）は集中切梁傾向あり & 図2 5 \\
\hline $\begin{array}{l}\text { 地下水位差が大きい場合（>6m）は地盤ア劢は選択 } \\
\text { されない傾向あり }\end{array}$ & 図2 2 \\
\hline 逆打の場合は工期が短い傾向がある & 図26 \\
\hline
\end{tabular}
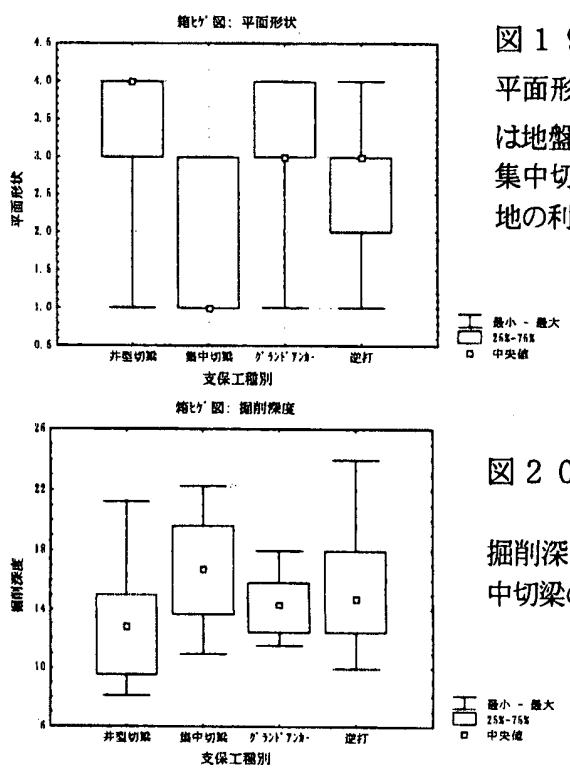

図 19

平面形状複雑なもの は地盤ア劢傾向あり 集中切梁は整形な土 地の利用が多い

20

㴰深度が大きいと集 切梁の傾向あり 

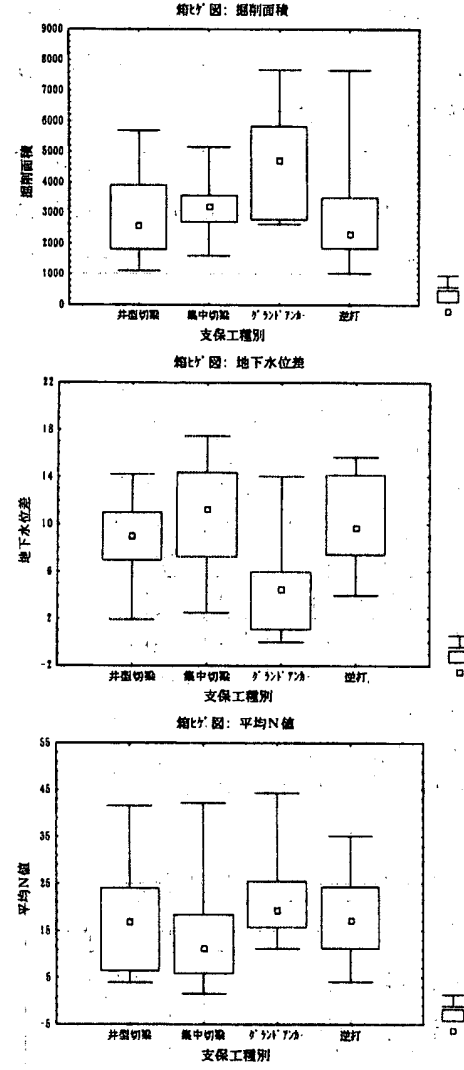

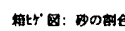

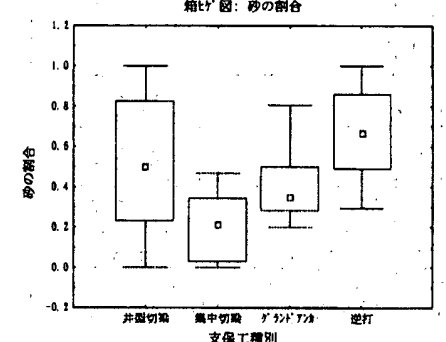

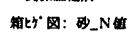
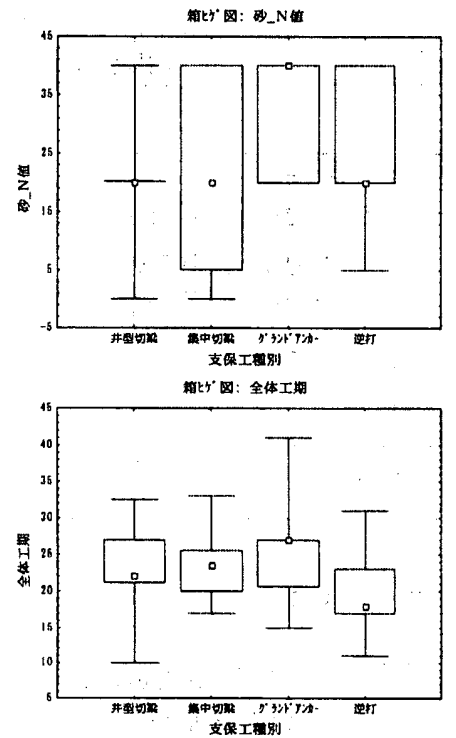

図 26

逆打の場合は工期短 い傾向あり

次に、B ソーンにある井型切梁の選定理由について考察する。該 当する事例について判別関数に当てはめて、集中切梁、地盤アンカ 一、逆打のどの領域に落ちるかを図 27 に示す。

B ソーンで井型切梁が採用されるケースは判別空間の逆打領域に ある場合が多い。箱ヒゲ図による比較でも図 $21 \sim 25$ では逆打と 似た傾向を示している。図 19 によると敷地平面形状が不整形のも
のに圧倒的に多いことがわかる。但し、井型切梁とは言っても実態 は補強を施したH型鋼材単材による特殊な割り付けの、かなり複雑 な架構ということが言える。

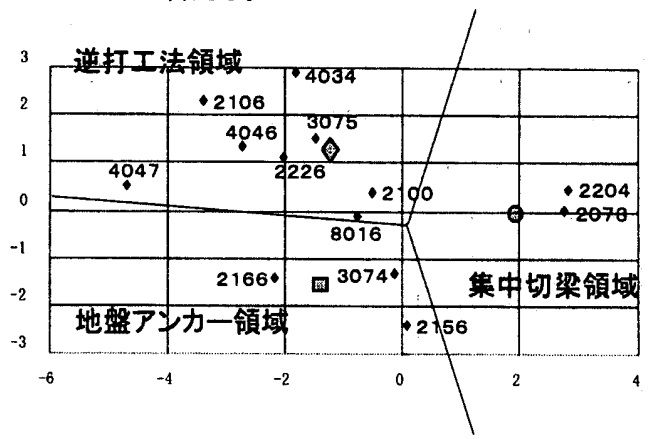

図 27 B ゾーンにある井型切梁の判別空間内の位置 （数值はサンプル番号）

図2 7 にプロットされた井型切梁事例について、各領域ごとに考察 を加えた結果を表 8 に示す。

表 8 B ソーンにある井型切梁の選定理由考察

\begin{tabular}{|l|l|l|r|}
\hline $\begin{array}{l}\text { 条件 } \\
\text { No. }\end{array}$ & $\begin{array}{l}\text { 該当 } \\
\text { 領域 }\end{array}$ & 井型切梁選定理由 & 件数 \\
\hline B-1 & 集中切梁 & 多角形で集中切梁が架けにくい & 1 \\
\hline B-2 & 集中切梁 & Aソーンに近い & 1 \\
\hline B-3 & 地盤アか- & $\begin{array}{l}\text { 近隣の制約でアンカーが打てな } \\
\text { い }\end{array}$ & 2 \\
\hline B-4 & 地盤アか- & $\begin{array}{l}\text { 規模・形状的にはアンカーが最 } \\
\text { 適のようだが、細長い敷地かつ } \\
\text { 地盤が軟弱 }\end{array}$ & 1 \\
\hline B-5 & $\begin{array}{l}\text { 逆打下構造上（杭無し、RCなど） } \\
\text { 支持真柱の採用に難点がある }\end{array}$ & 4 \\
\hline
\end{tabular}

\section{3. 山留支保工選定モテルの提案}

以上述べてきた分析結果より、山留支保工選定の手順を以下のよ うに考える。

\section{1 インブット条件の调盁}

今回の分析対象とした 9 つの説明変数の内、判別分析で判別関数 に含まれなかった粘土のN值を除く 8 項目をインプット条件とする。
(1) 掘削深度
(2) 掘削面積
(3) 敷地平面形状
(5) 平均 $\mathrm{N}$ 値
(4) 水位差
(6). 砂の割合
(7) 砂のN値
(8) 全体工期

\section{2 ソーンの特定}

掘削深度、掘削面積よりどのソーンに属しているかを特定する。

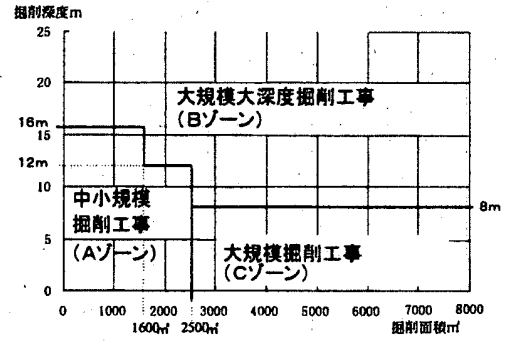

図28 支保工選定ソーン 


\section{3 Aソーンに属している城合の工法遇定}

Aソーンは井型切梁ソーンである。基本的には井型切梁を採用す る。但し、今回は分析対象外としたが、掘削深度が浅く、地盤が良 い場合は自立・法切工法の採用可否を別途検討すべきである。

\section{4 Aソーンでの特殊条件のチェック}

次に、Aソーンでの井型切梁以外の工法の採用条件を表 9 の条件 No.（A-1〜A-6）（表 3より導き出された）に従ってチェッ クし選定する。

表 9 Aグループソーンでの井型切梁以外を選定する条件

\begin{tabular}{|c|c|c|}
\hline No. & 選択条件 & 選択工法 \\
\hline$A-1$ & $\begin{array}{l}\text { 細長い数地で短辺巾が井型を組むほ } \\
\text { ど広くない場合 }\end{array}$ & $\begin{array}{l}\text { 長手両端を火打 } \\
\text { 梁とし、一方 } \\
\text { 向の集中切梁 }\end{array}$ \\
\hline$A-3$ & $\begin{array}{l}\text { 敷地高低差がある、または } 1 \text { 辺が隣 } \\
\text { 接建物の地下で切梁が架けにくい }\end{array}$ & 地盤ア劢 \\
\hline$A-4$ & $\begin{aligned} & \text { 地盤条件が悪い） }(\text { 平均 } \mathrm{N} \text { 值 }<=15 ） \\
&(\text { 砂のN } \mathrm{N} \text { 值 }<=15) \\
&(\text { 粘土N値 }<=2 ） \\
&(\text { 水位差 }>=4.5 \mathrm{~m}) \\
& \text { (かつ、掘削深度 }>8 \mathrm{~m} \text { ) }\end{aligned}$ & 逆打 \\
\hline$A-5$ & 敷地不整形 (かつ、掘削深度 $>8 \mathrm{~m}$ ) & 逆打 \\
\hline$A-6$ & 周辺道路が狭く、作業床が必要 & 逆打 \\
\hline
\end{tabular}

注） $\mathrm{A}$-2の条件は特殊なので選定のための条件からは除いた。

\section{5 Bソーンに属している場合の工法避定}

Bソーンの場合は式 1、式 2により正準判別を行う。

$X=-3.95698 \times$ 砂の割合 $-1.06886 \times$ 平面形状 $-0.01516 \times$ 地下水位差

$-0.03358 \times$ 平均 $\mathrm{N}$ 値 $-0.00013 \times$ 掘削面楼 $+0.157228 \times$ 掘削深度

$-0.03424 \times$ 砂のN値 $+0.007622 \times$ 全体工期 +3.567565 式 1

$Y=3.910225 \times$ 砂の割合 $-0.09166 \times$ 平面形状 $+0.098696 \times$ 地下水位差

$-0.07553 \times$ 平均 $\mathrm{N}$ 値 $-0.00028 \times$ 掘削面樌 $+0.126627 \times$ 掘削深度

$-0.01514 \times$ 砂のN値 $-0.06897 \times$ 全体工期 +0.009001 式2

\section{6 Bソーンでの特殊条件のチェック}

判別空間内の位置（領域境界や重心から遠い場合）による判定に ついては表 5 に示した通り特に重視しなくて良い。

次に、Bゾーン内で集中切梁、地盤アンカー、逆打でなく井型切

梁による架構を余儀なくさせられる条件を表 10 （表８より導き出 された）によりチェックする。

表 10 Bソーンで井型切梁を選定する条件

\begin{tabular}{|c|c|c|}
\hline No. & 井型切梁選定理由 & $\begin{array}{l}\text { 該当する } \\
\text { 判別 架間の領 } \\
\text { 域 }\end{array}$ \\
\hline$B-1$ & 多角形で集中切梁が架けにくい & 集中切梁 \\
\hline B -2 & Aグループソーンに近い & 集中切梁 \\
\hline$B-3$ & 近隣の制約でアンカーが打てない & 地盤ア劢- \\
\hline$B-4$ & $\begin{array}{l}\text { 規模・形状的にはアンカーが最適のよ } \\
\text { うだが、細長い敷地かつ地盤が軟弱 }\end{array}$ & 地盤ア劢- \\
\hline$B-5$ & $\begin{array}{l}\text { 地下構造上（杭無し、RCなど）支持 } \\
\text { 真柱の採用に難点がある }\end{array}$ & 逆打 \\
\hline
\end{tabular}

B-6の条件は本来逆打が適していると判断されるので井型切梁選 定条件には含まれない。

\section{7 Cソーンに属している岈合。}

このゾンンは浅くて広大な掘削となるので、工区分けを考慮し、 基礎、躯体工事の工程手順を考えながら工法決定をすることになる。 広域にわたるため今回は選定ロジック提案から除外する。

\section{4. 曹例による㛟柾}

次に、分析対象以外の事例を選び検証を行った。対象デー夕は最 近の工事（1981 年〜1997 年）で雑誌等に発表された事例 ${ }^{6}$ ～３3) から 井型切梁： 15 件、集中切梁： 3 件、地盤アンカー：6 件、逆打： 15 件を無作為に抽出した。

A、B各ソーン毎のサンプル数を図 29 に示す。

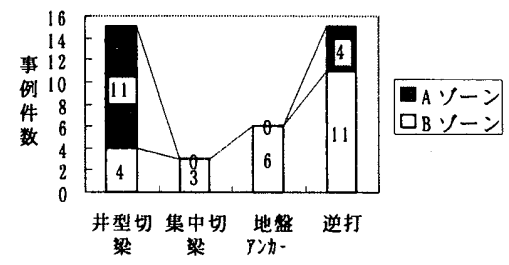

図29 検証データのヒストグラム

雑誌等に発表された事例では全体的にBソーンに属する事例が多

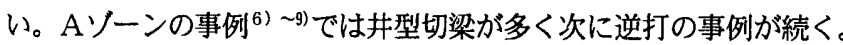
検証データからみても、Aソーンは井型切梁ソーンと言える。井型 切梁以外が採用される条件はすでに述べたように、客観的な地盤条 件等以外の要因で決まることが多いため、ここではこれ以上の検討 は割愛する。Bソーンは発表事例の多さからも判る通り工事全体に 対する重要度が高いことがうかがえる。以下にBソーンの検証及び 考察を行なう。

Bソーンについては判別分析結果より導き出された式 1 、式 2 に より推定を行った（表 11 1)。Bゾーンの提案モデルの検証結果と しては集中切梁、地盤アンカー、逆打の推定精度は全体で $80 \%$ と かなり信頼できる值を示している。

表 11 Bソーンの山留支保工選定モデルの検証

\begin{tabular}{|l|l|l|r|r|r|r|}
\hline & 件 & \multicolumn{3}{|c|}{ 提案モデルによる工法推定結果 } & 推定的中 \\
\cline { 3 - 6 } 真の群 & 数 & 井型 & 集中 & ア劢 & 逆打 & 率 (\%) \\
\hline 井型切梁 & 4 & & $(3)$ & $(1)$ & & $\%$ \\
\hline 集中切梁 & 3 & & 3 & & & $100 \%$ \\
\hline 地盤ア劢 & 6 & & 1 & 5 & & $83 \%$ \\
\hline 逆打 & 11 & & 3 & & 8 & $73 \%$ \\
\hline 合計 & 24 & & 10 & 6 & 8 & $80 \%$ \\
\hline
\end{tabular}

また、図 30 に検証デー夕についてすでに求めた判別式 1）2） を適用し、判別空間内の位置をプロットした。

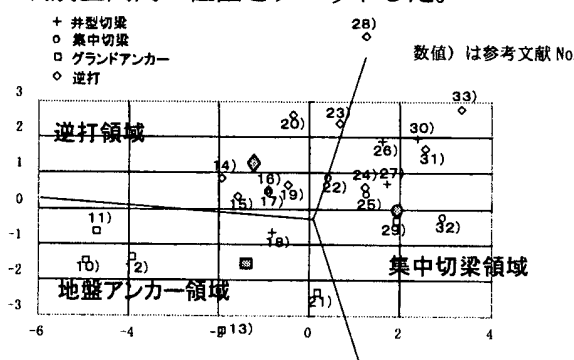

図３０Ｂゾーンにある検証データの判別空間内の位置 サンプル中に井型切梁の事例が 4 例含まれていたが、集中切梁と 
推定された 3 例 ${ }^{26)}$ 27) 30) は表 10 の条件B-2のAソーンに近いも のであった。また、地盤アンカーと推定されたもの ${ }^{18)}$ は近隣条件が 地盤アンカー施工を許さなかった（表 10 の条件B－3）と文献に は記述されている。検証データで特徴的なことは集中切梁領域に集 中切梁以外の工法がかなり見られることである。集中切梁が適当と 判断された地盤アンカーの事例 ${ }^{29}$ は掘削深度が深いことが影響して いるようだが、実際は法切、アイランド工法を一部併用している。 大規模で複合的に工法を併用する場合については更に検討が必要で ある。また、集中切梁領域に入った逆打事例 24)31133) が 3 件あった。 これらの内 1 例 ${ }^{24)}$ は周辺環境を考虑して発注者から工法指定があっ たものである。また残り 2 例 ${ }^{31}{ }^{33)}$ は品質向上や工期短縮を目指した 新技術開発の事例であった。今後、ますます近隣環境への配慮が求 められ、安全性を考慮した逆打工法（本設躯体利用）が増えていく 萌芽が読み取れる。

\section{5. 結言}

本研究では「山留支保工の選定」に関して次のような結論とその 技術的な考察を行った。

(1) 山留支保工計画にあたっては掘削深度、掘削面積によりA，

B，Cの3ソーンに分けて工法を検討すると、各工法の推定が 簡明となる。

(2) Aソーン (中小規模掘削工事) にあたる工事は井型切梁工法 で殆どのものが対応可能であることを示した。また、井型切梁 以外を選定すべき条件を示した。

(3) Bソーン（大規模大深度掘削工事）に関しては統計的手法に より工法選定のための正準判別式を示した。

以上から、山留工事の専門家でなくても、客観的な地盤条件等の データで山留計画の初期方針を立てることの可能性を示した。

今後の研究課題としては、今回の研究では盛り込めなかうた工法 選定上の要因（建物基礎形式との兼ね合い、近接構造物、道路等の 近隣環境、敷地境界線と掘削領域の関係、工期、経済性等）につい ての定量的な分析を行い、施工計画管理の適正化を進めていきたい と考えている。

\section{䀣辞}

本論文をまとめるにあたり、早䈱田大学名誉教授 田村恭先生に は、研究全般についてご指導を頂きました。又、早稲田大学教授 嘉 納先生には、その具体的内容について直接のご指導、ご鞭撻を賜り 心より御礼申し上げます。

又、早稲田大学院生 金澤英紀氏、信田直裕氏、安冨彩子氏には データ収集・解析に多大のご協力を頂きました。

大成建設株式会社 深海謙吉氏はじめ、各工事関係者には資料収 集、整理にあたりご協力を頂きました。

\section{ここに感謝の意を表します。}

\section{考文献}

1）山下丞二、間瀨惊平：山留工事の設計施工 1996.7 初版P 4 P 7 P 3 4 P 36 井上書院

2) 山留設計施工指針：1988. 1 第 2 版 P $23 \sim P 27$ 日本建築学会

3）嘉納成男、間瀬悸平、金沢英紀、信田直裕、安富彩子： 山留壁の工法推定モテルとその推定精度の比較（論文）

4）安富彩子、嘉納成男、金沢英紀、住田直裕、間瀬嵉平: 地下工事における実績資料の統計的分析 (その3) 判別分析による山留支保工の推定、1996 年
日本建築学会関東支部研究報告集、P 345 ～P 348

5) 間瀬悸平 : 建築工事における大規模・大深度拥削の設計と施工 1990. 7 r基磷工」 P $86 \sim$ P 89

6）建築技術 1995 年 3 月号

7）建築技術 1996 年 4 月号

8）建築技術 1997 年6月号

9）根切山留の設計施工シンポジウム論文集 1998 年 2 月 地盤工学会

10）小林利昭、工藤信芳、小野寺常昭 :

パルクアベニュー川徳新築工事における山留め工事、基礎工、 1982 年 4 月 P 8 4 P 94

11）向山执美、北村孝海 : 水沢市庁舎新築工事における根切りと地下水対策、基碟 I.

1982 年 4 月、P $75 \sim$ P 83

12）綿野善唯、片桐央雄、㮛波信一：金沢市香林坊A T R IOの基嘫・山留め工事、 基硔工、1988 年 3 月、P $108 \sim \mathrm{P} 111$

13）黒田满男、是石逸二、水野憲雄、宫沢徹、間瀬慞平 : 大崎駅前再開発における事例、基礎工、1985 年7月、P $104 \sim P 113$

14）三町直志、大野宏行、居谷善司 : 竹芝ふ頭再開発第 3 期工事における逆打ち工 法,

基碳工、1993年 9 月、P $37 \sim$ P 41

15）小林英雄、山田暂夫、森勉、広田哲夫： 工業化逆打ち工法一常和新横浜ビルにおけるリバース樌層工法の施工、基礎工、 1993 年 9 月、P $48 \sim$ P 55

16）川崎孝人、幾田愁康、丸岡正夫、三苫孝文、松井攻、矢作孝雄 : 高い被圧地下水を有した軟弱地盤における工事例

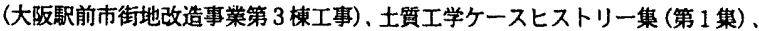
1983 年、P $216 \sim 223$

17）山本知由、小西昭臣 : 聖路加国際病院第三街区建設工事における逆打ち工法、 基礎工、1993年 9 月、P $31 \sim$ P 36

18）福留央郎、中島康次郎、石井貞美、松島潤： 前面道路に $45^{\circ}$ の軸線をもつ变形教地における大規模山留め工事の計画と夷

施

(新日鉱ビル建設工事)，基硙工、1989 年2月、P 114 ～P 119

19）石塚秀教、角谷生起、桶口清笨、尾绮徹也： 福塥県国際会館(仮称) 新築工事の逆打亏工事、基礎工、 1993 年 9 月, P $56 \sim$ P 62

20）山崎進、安田邦治、僟貝光章、遠山祐二 : 住友猿楽町ビルにおける逆打ち工法、 基䃈工、1993 年 9 月、P $98 \sim$ P 105

21）吉成元伸、間瀨惊平、新海潡一、国藤祥光: ソイルセメント山留め壁の設計之施工(東京都第一本庁舎における SMW施工 例)、基鿎工、1988 年8月、P $66 \sim$ P 67

23）垣田英策、宮田孝志 : 軟弱地盤における山留め工事の計测による予測管理 （北九州第二竹舎）、基整工、1981 年 12 月、P $43 \sim$ P 51

24）白塚芳郎、渡辺一茂、小林正則、大路英昭： 市街地における地下瓷電所の逆打ち工法。基礎工、 1993 年 9 月、P $78 \sim$ P 84

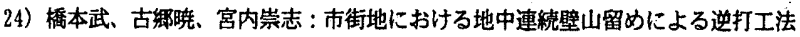
（赤坂電話局新築工事）、基礎工、1981 年6月、P. $50 \sim P 57$

25）菊地祐悦、菊地秀行 : 青山地区の大規模地下工事(新背山ビル)基礎工 1981 年 6 月、P $47 \sim P 49$

26）黑岩恭浩、井村芳郎、細川袥司、丸田洋二 : 宮崎電報電話局別棟新築工事にお け

る杭·山留め工事、基礎工、1981 年12月、P $102 \sim P 115$

27）菊地咗悦、菊地秀行：䇌山地区の大規模地下工事（青山電々）基礎工、 1981 年 6 月、P 46

28）水野修己、岩堀守恭、岐部哲朗 : 名古屋市内における大深度地下变電所の施工 例、

基磷工、1990年 1 月、 P $107 \sim \mathrm{P} 113$

29）寺尾嘉夫 : 新宿野村ビル建設時の大規模把削の合理的な施工、基礎工、 1981 年 6 月、P $58 \sim$ P 65

30）菊地祐悦、菊地秀行 : 青山地区の大規模地下工事（ハザマビル）基礎工、 1981 年 6 月、P 46

31）野尻明美 : 仮想支点法により逆解析した逆打事例 2 題（事例(2)）建策技術、 1995 年3月、P $117 \sim$ P 119

32）鈴木征志、中山正朗、吉田昌和: 三菱銀行本館新築工事(地下工事の計画と実

施)

基碳工、1981 年 6 月、P $105 \sim$ P.1 15

33）守武亮、磯畸聡 : テレコムセンタービル建設工事における逆打工法計面基礎工、 1993 年 9 月、P $42 \sim$ P. 47

（1998年 3 月30日原稿受理；1998年 9 月 9 日採用決定） 